\title{
Maximum leaf photosynthetic light response for three species in a transitional tropical forest in Southern Amazonia
}

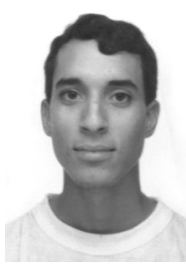

\author{
Eduardo J. Miranda ${ }^{1}$, Nicolau Priante Filho ${ }^{1,2}$, Pedro C. Priante ${ }^{1}$, José H. Campelo Jr. ${ }^{1}$, \\ George S. Suli ${ }^{3}$, Clóvis L. Fritzen ${ }^{4}$, José de S. Nogueira ${ }^{2} \&$ George L. Vourlitis ${ }^{5}$ \\ 1 Núcleo de Tecnologia em Armazenamento, UFMT. Cuiabá, MT, Brazil. E-mail: aquaviva@terra.com.br \\ ${ }^{5}$ California State University, San Marcos, CA 92096, USA. E-mail: georgev@mailhost1.csusm.edu
}

2 Departamento de Física, UFMT. E-mail: nogueira@cpd.ufmt.br

${ }^{3}$ Departamento de Física/UFMT. E-mail: suli@nutecnet.com.br

${ }^{4}$ Departamento de Matemática/UFMS. Corumbá, MS. E-mail: cfritzen@ceuc.ufms.br

Protocolo 68 - 24/4/2003 - Aprovado em 16/12/2003

\begin{abstract}
Measurements of $\mathrm{CO}_{2}$ and water vapor flux using eddy covariance are being made from a $40 \mathrm{~m}$ tower located in a transitional tropical forest near Sinop Mato Grosso. As complementary information to this study, the photosynthetic light response curves of three species located near the tower were measured at different heights in the forest canopy and light conditions with the objective of understanding seasonal and spatial (height in the forest canopy and gap or shade located plants) trends in the photosynthetic light response. The measurements were made in a canopy emergent tree $(30 \mathrm{~m}$ tall) identified as Brosimum lactescens, and in two relatively short plants (0.6 to $1.6 \mathrm{~m}$ height) identified as Quiina pteridophylla and Diniszia excelsa located in different light condition. Measurements were made from the end of 2000 dry season to January 2002. These data suggest that species response to seasonal variations in rainfall are variable. In addition, shade plants have a higher quantum yield $(A)$ and a lower estimated gross photosynthesis at saturating (photosynthetic active radiation - PAR) $\left(A_{\max }\right)$ than gap plants, presumably because shade plants are adapted to lower average light levels.
\end{abstract}

Key words: Eddy covariance, tropical forest, photosynthetic light

\section{Máxima resposta à luz fotossintética nas folhas de três espécies de planta em uma floresta tropical de transição ao Sul da Amazônia}

\begin{abstract}
Resumo: Medidas de fluxo de $\mathrm{CO}_{2}$ e de vapor d'água que usa o método de vórtices turbulentos estão sendo feitas em uma torre de $40 \mathrm{~m}$, situada em uma floresta tropical de transição perto da cidade de Sinop no Estado de Mato Grosso. Como informação complementar a este estudo, curvas de resposta à luz de três plantas situadas perto da torre, foram medidas em diferentes alturas em relação ao dossel da floresta e condições de luz. Tendo como objetivo, compreender as tendências sazonais e espaciais (altura no dossel da floresta e plantas sob copa ou em clareiras) da fotossíntese. As medidas foram feitas em uma árvore emergente do dossel (30 $\mathrm{m}$ de altura) identificada como Brosimum lactescens, e em duas plantas de sub-bosque (altura de 0,6 a 1,6 m) identificadas como Quiina pteridophylla e Diniszia excelsa situadas em diferentes condições de luminosidade. As medidas foram feitas a partir do final da estação seca de 2000 até janeiro de 2002. Estes dados sugerem que as respostas das espécies às variações sazonais (precipitação) são variáveis. Além disso, as plantas de sombra tiveram um maior rendimento fotossintético (A) e uma fotossíntese bruta estimada mais baixa com saturação de radiação fotossinteticamente ativa (Amax) do que plantas de clareira, possivelmente porque as plantas de sombra são adaptadas a níveis médios de luz mais baixos.
\end{abstract}

Palavras-chave: Vórtices turbulentos, floresta tropical, luz fotossintética

\section{INTRODUCTION}

In a natural forest there is a great variation in the physiological behavior of plants due to different microenvironment conditions. It is well known that the light conditions in forest under canopy are very variable. In the transitional tropical forest the light conditions under canopy also change with the seasonality, due to a higher litter fall in the dry season.

It is known that different light conditions are one of the main causes of different physiological responses, for example plants growing in forest under canopy often exhibit an enhanced 
photosynthetic performance under variable light regimes (Ogren \& Sunding1996; Valladares et al., 1997). Also for these plants utilization of brief high light sunflecks has been shown to contribute a significant percentage of total carbon gain (Pfitsch $\&$ Pearcy 1989), for a large fraction of the light intercepted by shade plants in both temperate and tropical forest originated from clusters of short sunflecks separated by longer period of diffuse light (Pearcy, 1990). Thus shade plants should have a low maximum photosynthesis at saturating $\operatorname{PAR}\left(\mathrm{A}_{\max }\right)$ and dark respiration rate at $0{ }^{\circ} \mathrm{C}(\mathrm{Rd})$ but a high quantum yield (A).

On the other hand plants growing on forest gaps receive more direct sunlight and so its behavior is different. In order to optimize its light availability these plants have a high $\mathrm{A}_{\max }$ and Rd but a low $\mathrm{Q}$. These result are expected from any shade and gap plant in normal ambient conditions, but as it is well documented in a natural environment, this condition may have a large variation due to seasonality. So what would happen in a water stress scenario, where gap plants receiving more direct sun light would suffer more than a shade plant? And what about canopy emergent trees; will water stress that affect saplings also affect a full-grown tree? Probably not, but as the dry season extends it should have some consequence on the tree. But, will the shade and gap leaves of the same canopy emergent trees react differently?

There are many papers that studied the physiology of tropical plants most of them were on Barro Colorado Island and a few were with Amazon species. However, no data exists for tropical transitional forests (cerradão) that occupy the ecotone between wet evergreen forest of the central Amazon Basin and the drier tropical savanna and seasonally deciduous forest of eastern and southern Amazonia.

With the objective of answering questions of seasonal and spatial variations in plant physiology, for this particular region, the photosynthetic light response curve of three species was measured using constant light conditions for each measured point of the curve. The plants were growing in natural different light environments: forest under canopy, small forest gaps, and canopy trees.

\section{MATERIAL AND METHODS}

\section{Site description}

The study area is located near the city of Sinop, Mato Grosso, Brazil (11 ${ }^{\circ} 24.75^{\prime} \mathrm{S}: 55^{\circ} 19.50^{\prime} \mathrm{W}$ ) (Fig. 1), which is located near the ecotone of two major regional ecosystem types of South America (wet evergreen rain forest and tropical savanna). The mean annual temperature is $24.1{ }^{\circ} \mathrm{C}$, and the mean rainfall is $2 \mathrm{~m} /$ year. There are two well-defined seasons, DecemberFebruary being the wet season and June-August is the dry season. The data analysis was divided into wet, transition wetdry (March to May), dry and transition dry-wet (September to November) seasons. Soils are Ultisols, which are the dominant soil type of the Brazilian Amazon Basin (Moraes et al., 1995).

In this site there is a tower based eddy covariance system where precipitation has been measured above the canopy using a tipping-bucket rain gauge (Sierra Misco, model 2501). Micrometeorological data were averaged over half hour intervals

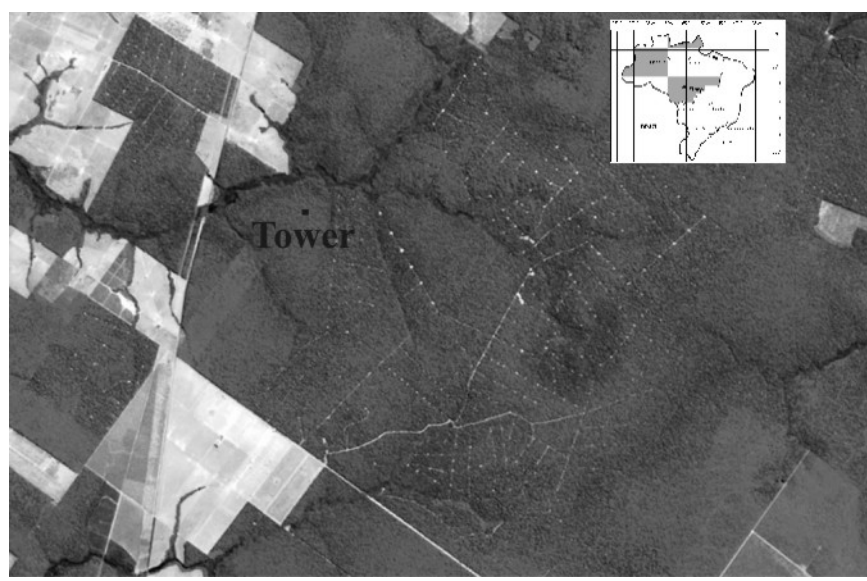

Figura 1. Landsat of the tower location

from observations made every 60s and stored using a multiplex data logger (Campbell Scientific, model CR10X).

\section{Species}

Measurements were made on three species, two of these are Quina pteridophylla and Dinizia excelsa, 1-1.5 m tall saplings that were growing under the canopy (hereafter referred to as shade plants; $\mathrm{n}=2$ plants per species) or in canopy gaps (hereafter referred to as gap plants; $\mathrm{n}=3$ plants per species). The other specie was a full grown tree, $32 \mathrm{~m}$ canopy emergent, Brosimum lactescens, the measurements were made on leaves at 18 and $26 \mathrm{~m}$ above ground level $(\mathrm{n}=1$ plant located adjacent to the eddy flux tower).

\section{Photosynthetic gas exchange}

Photosynthetic light response curves were measured using a portable photosynthesis system (model LI-6400, LI-COR, Lincoln, NE., USA). Leaves were exposed to $400 \mathrm{ppm} \mathrm{CO}_{2}$ concentration and the photosynthetic active radiation (PAR) values of 2000, 1500, 1000, 800, 400, 200, 100, 50 and $0 \mu \mathrm{mol} \mathrm{m}^{-2} \mathrm{~s}^{-1}$. Temperature was set at $28^{\circ} \mathrm{C}$ with a variation of 2 degrees for most measurements, and relative humidity was controlled between 60 and $80 \%$.

All data presented in this article were fitted to the model given below with the program CurveExpert (version 1.3; Daniel Hyams; MS, USA) with $\mathrm{r}^{2}$ values over 0.95 .

The model used to estimate light saturated photosynthesis as a function of PAR is given by Ruiny et al. (1995) and Vourlites \& Oechel (1999).

$$
F_{c}(Q)=\left(\frac{A Q A_{\max }}{A Q+A_{\max }}\right)-R_{d}
$$

where, $\mathrm{F}_{\mathrm{c}}$ is the net leaf exchange (net leaf photosynthesis); $\mathrm{A}$ is the estimated quantum yield $\left(\mu \mathrm{mol} \mathrm{CO} \mathrm{CO}_{2}(\mu \mathrm{mol} \mathrm{Q})^{-1}\right)$; Q is the instantaneous photosynthetic active radiation $\left(\mu \mathrm{mol} \mathrm{m} \mathrm{m}^{-2} \mathrm{~s}^{-1}\right)$; $\mathrm{A}_{\max }$ is the estimated $\mathrm{CO}_{2}$ exchange at saturating PPFD (photosynthetic photon flux density) or estimated gross photosynthesis at saturating PAR $\left(\mu \mathrm{mol} \mathrm{Q} \mathrm{m}^{-2} \mathrm{~s}^{-1}\right)$; and $\mathrm{R}_{\mathrm{d}}$ is the estimated dark respiration rate at $0^{\circ} \mathrm{C}\left(\mu \mathrm{mol} \mathrm{CO}_{2} \mathrm{~m}^{-2} \mathrm{~s}^{-1}\right)$. 


\section{RESULTS AND DISCUSSION}

The $A_{\max }$ varied between species but there was a clear seasonal trend. All plants had a greater $\mathrm{A}_{\max }$ in the wet season while the lowest values occurred at the end of the dry season.

Mean dry values for $Q$. pteridophylla were $5.0 \pm 0.8$ and $5.9 \pm 1.6 \mu \mathrm{mol} \mathrm{m}^{-2} \mathrm{~s}^{-1}$ respectively for 2000 and 2001 while in the wet period $\mathrm{A}_{\max }$ were $9.8 \pm 1.0$ and $10.9 \pm 1.4 \mu \mathrm{mol} \mathrm{m}^{-2} \mathrm{~s}^{-1}$ for 2001 and 2002. For $D$. excelsa the values were $6.7 \pm 1.9 \mu \mathrm{mol} \mathrm{m}^{-2} \mathrm{~s}^{-1}$ for 2001 dry season. For 2001 and 2002 wet periods the values were respectively, $11.5 \pm 2.8$ and $13.4 \pm 2.3 \mu \mathrm{mol} \mathrm{m}^{-2} \mathrm{~s}^{-1}$. This trend can be clearly seen in Figure 2. Although there is a low Jan/01 measurement for the $Q$. pteridophylla, it is probably not a seasonal trend but a response due to a particular day condition of January 13 , a cloudy with a low temperature. The average air temperature for $\mathrm{Jan} / 01$, at the measurement height was $24.5^{\circ} \mathrm{C}$ while for Nov/00 and Jun/01 it was 27.3 and $29.5^{\circ} \mathrm{C}$, respectively. The D. excelsa measurements were made on January 14, when the weather condition was better, (higher temperature $25.5^{\circ} \mathrm{C}$ and clear sky). This explains the large difference between the measurements of both species for the same month, January 2001.

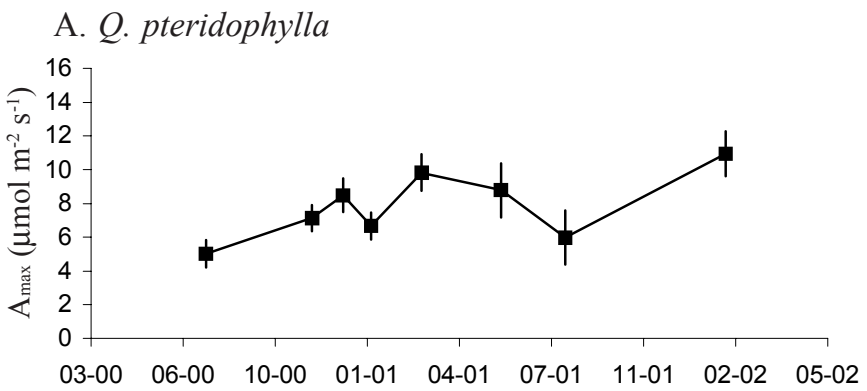

B. D. excelsa

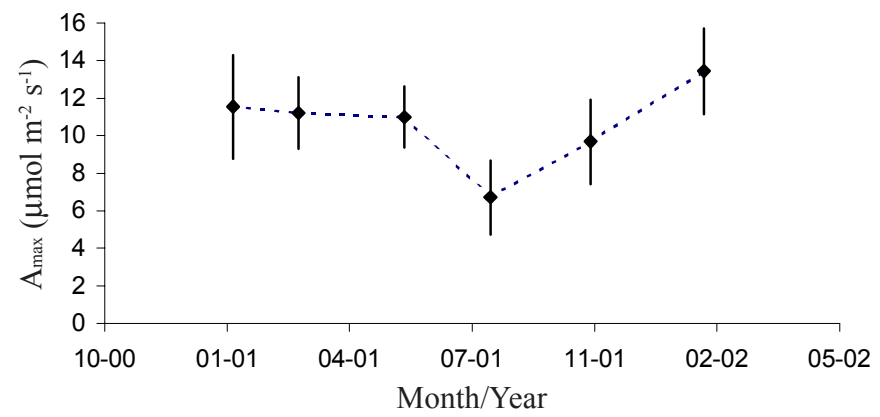

Figure 2. Estimated mean $\mathrm{A}_{\max }$ for all plants of (A) Q. pteridophylla and (B) D. excelsa, on different dates

In Figure 3, the difference in physiological behavior of gap and shade plants of both species may be observed. The Q.pteridophylla gap plants had a larger drop of $\mathrm{A}_{\max }$ than the shade plants in Jan $/ 01$, which is expected because the shade plants are more adapted to low light and temperature.

Gap plants had a larger $\mathrm{A}_{\max }$ than shade plants probably because shade plants are adapted to lower average light levels. The D. excelsa had the greater significant difference of

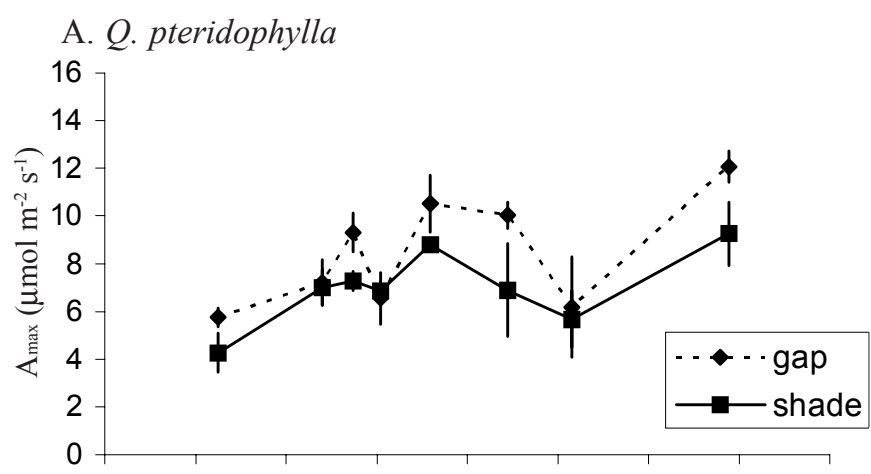

03-00 06-00 10-00 01-01 04-01 07-01 11-01 02-02 05-02 B. D. excelsa

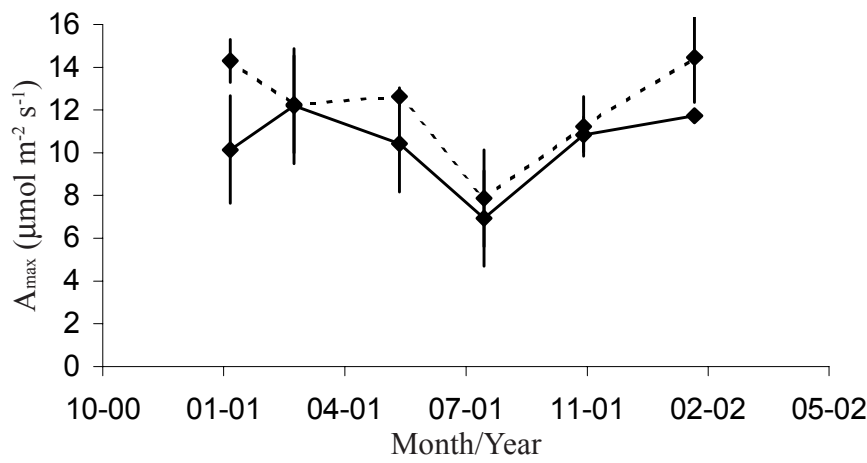

Figure 3. $\mathrm{A}_{\max }$ for (A) Q. pteridophyla and (B) D. excelsa in different light conditions (gap and shade)

$4.2 \mu \mathrm{mol} \mathrm{m} \mathrm{m}^{-2} \mathrm{~s}^{-1}$ but only in the wet season, Jan/01. $Q$. pteridophylla had a lower maximum difference of $3.1 \mu \mathrm{mol}$ $\mathrm{m}^{-2} \mathrm{~s}^{-1}$ in the beginning of the dry season, Jun/01, but also presented a significant difference in Jul/00, Nov/00, Apr/01 and Fev/02 (Fig. 3).

The ecosystem $A_{\max }$ for January, February, and April 2001 (estimated from eddy covariance measurements) was 16.9, 23.1, and $20.2 \mu \mathrm{mol} \mathrm{m}^{-2} \mathrm{~s}^{-1}$, respectively, while the average $\mathrm{A}_{\max }$ for Brosimum lactescens during the same months was 9.1, 10.5 and $10.5 \mu \mathrm{mol} \mathrm{m}^{-2} \mathrm{~s}^{-1}$ (Fig. 4). The larger ecosystem $\mathrm{A}_{\max }$ reflects the contribution of many different species to the total ecosystem photosynthesis. The largest difference between the Brosimum lactescens leaves and the ecosystem over the January-April 2001 period was observed for dark respiration (Rd), where the individual Brosimum lactescens leaves had an average $\mathrm{Rd}$ of $0.85 \mu \mathrm{mol} \mathrm{m}{ }^{-2} \mathrm{~s}^{-1}$ while the ecosystem had an average $\mathrm{R}_{\mathrm{d}}$ of $6.7 \mu \mathrm{mol} \mathrm{m}^{-2} \mathrm{~s}^{-1}$ (Fig. 4).

The leaves of the Brosimum lactescens at different heights showed a different physiological behavior (Fig 4). The leaves at the top of canopy, $26 \mathrm{~m}$, had a larger $\mathrm{A}_{\max }$ and Rd with a lower Q when compared to the leaves at $18 \mathrm{~m}$.

The larger ecosystem $R_{d}$ is expected given that the ecosystem $R_{d}$ includes respiratory contributions from stems, roots, fruits, and soil microbes in addition to leaves. To compare $\mathrm{A}_{\max }$ and $\mathrm{R}_{\mathrm{d}}$ values directly, it is necessary to correct the individual leaf values with the leaf area index (LAI). In this study the LAI was estimated using PPFD extinction in the canopy for this comparison. 

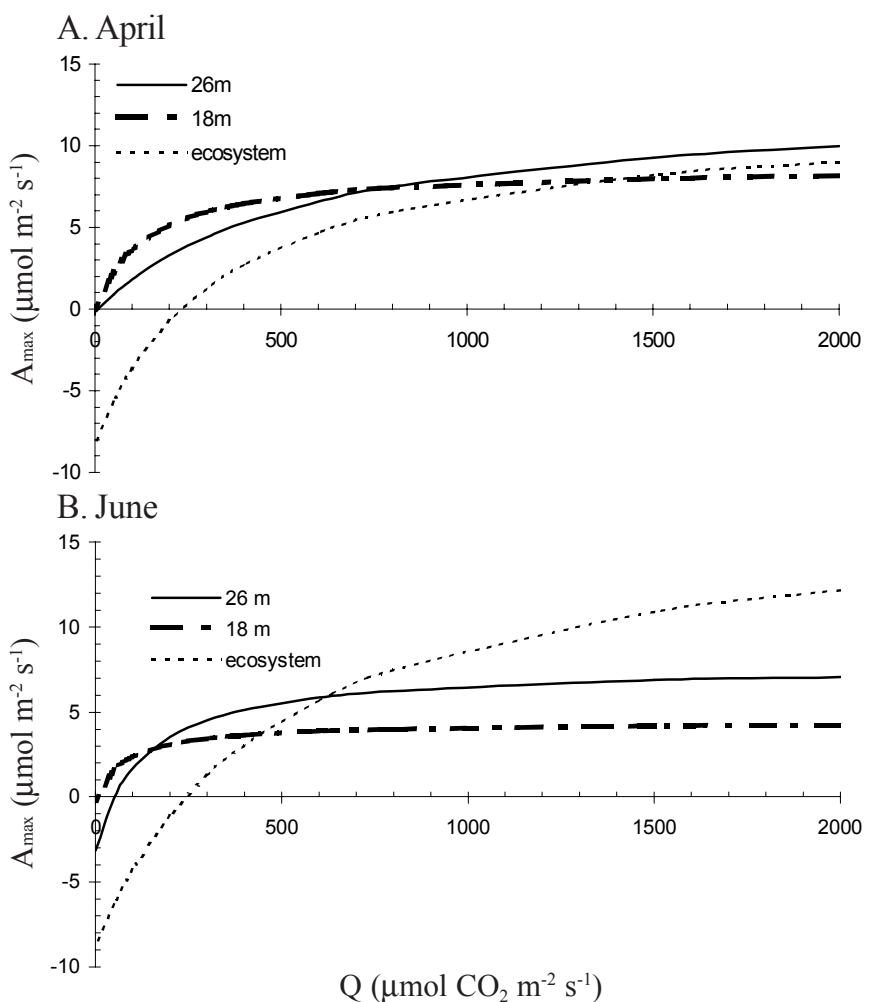

Figure 4. Light-response curves from leaves of the canopy tree (Brosimum lactescens) measured at different heights and from the ecosystem measured using eddy covariance in April and June, 2001

\section{CONCLUSION}

1. There is a significant increase of the light-saturated photosynthesis as water availability increases.

2. Shade plants have a higher quantum yield and a lower $\mathrm{A}_{\max }$ than gap plants, presumably because shade plants are adapted to lower average light levels.

3. Leaves from the same tree, Brosimum lactescens, at different heights showed different behavior, the ones at the top of the canopy had the characteristic of gap plants while the ones at the middle of the canopy were similar to shade plants.

4. Ecosystem values of $A_{\max }$ were generally higher compared to leaf levels of $\mathrm{A}_{\max }$, however, large differences in ecosystem and leaf Rd were observed because the ecosystem Rd includes respiration from non-leaf (i.e., stem, root, and fruit) and microbial components.

\section{ACKNOWLEDGMENTS}

Funding was provided by the the Conselho Nacional de Desenvolvimento Científico e Tecnológico (CNPq), and the Fundação de Amparo à Pesquisa do Estado de Mato Grosso (FAPEMAT). Additional support was provided by the Coordenação de Aperfeiçoamento de Pessoal de Nível Superior (CAPES) and the Instituto Nacional de Pesquisas Espaciais (INPE). Logistic support from Sindicato das Indústrias Madeireiras do Norte de Mato Grosso (SINDUSMAD), Maracaí Florestal e Industrial Ltda Fundação de Promoção Social do Estado de Mato Grosso (PROSOL), Corpo de Bombeiros do Estado de Mato Grosso and California State University, San Marcos (CSUSM), is gratefully appreciated.

\section{LITERATURE CITED}

Allen, M.T.; Pearcy, R.W. Stomatal behavior and Photosynthetic performance under dynamic light regimes in a seasonally dry tropical rain forest. Oecologia, Heidelberg, v. 122, p.470-478, 2000.

Moraes, J.L.; Cerri, C.C.; Melillo, J.M; Kicklighter, D.; Neill, C.; Skole, D.L.; Steudler, P.A.. Soil carbon stocks of the Brazilian Amazon basin. Soil Science Society of America Journal, Madison, v.59, p.244-247, 1995.

Ogren, E.; Sunding U. Photosynthetic response to variable light: a comparision of species from contrasting habitats. Oecologia, Heidelberg, v.106, p.18-27, 1996.

Pearcy, R.W. Sunflecks and photosynthesis in plant canopies. Annual Review of Physiology of Plant and Molecular Biology, New York, v.41, p. 421-453, 1990.

Pftish, W.A.; Pearcy, R.W. Steady-state and dynamics photosynthetic response of Adenocotaulon bicolor in its redwood forest habitat. Oecologia, Heidelberg, v.80, p.471476, 1989.

Ruimy, A.; Jarvis, P.G.; Baldocchi, D.D.; Saugier, B. CO2 fluxes over plant canopies and solar radiation: a review. Advances in Ecological Research, London, v.26, p.1-68, 1995.

Valladares, F.; Allen, M.T.; Pearcy, R.;W (1997) Photosynthetic responses of dynamic light under field conditions in six tropical rainforest shrubs occurring along a light gradient. Oecologia, Heidelberg, v.111, p.505-514, 1997

Vourlitis, G.L.; Oechel, W.C. Eddy covariance measurements of net $\mathrm{CO} 2$ flux and energy balance of an Alaskan moist-tussock tundra ecosystem. Ecology, Washington, DC, v.80, p.686701, 1999 . 